\title{
Digestive Enzymatic Responses of Chickens Feed-restricted and Refed as Affected by Age
}

\author{
Cristiane R. A. Duarte ${ }^{1}$, Maria L. M. Vicentini-Paulino ${ }^{2}$ and Daniela F. Pinheiro ${ }^{2}$ \\ ${ }^{1}$ Department of Animal Science, Universidade Estadual de Maringá (UEM). Av. Colombo, \\ 5790, Bloco j45, Maringá, Paraná, Brazil, 87020-900 \\ ${ }^{2}$ Department of Physiology, Biosciences Institute, Universidade Estadual Paulista (UNESP). \\ Distrito de Rubião Jr. s/n, Botucatu, São Paulo, Brazil, 18618-970
}

\begin{abstract}
The effect of feed restriction and refeeding on enzymatic activity and gastrointestinal organ weight was evaluated in chickens at two ages, 7 and $35 \mathrm{~d}$ of age. At each age, the birds were $70 \%$ feed-restricted for $7 \mathrm{~d}(30 \%$ of ad libitum intake) followed by ad libitum refeeding for $3 \mathrm{~d}$. The control groups were fed ad libitum during equivalent periods $(10 \mathrm{~d})$. Pancreatic activity of chymotrypsin, trypsin, amylase and lipase, and intestinal activity of sucrase and maltase were analyzed, and the weights of the proventriculus, gizzard, pancreas, small and large intestine were obtained. Trypsin and amylase activity were lower in the feed-restricted group than in the control groups at d14, whereas sucrase activity was lower in the feed-restricted group than in the control group at $\mathrm{d} 42$, showing that the effect of feed restriction on enzyme activity was age-dependent. Feed restriction decreased the weight of all organs in the starter and finisher periods. Upon refeeding, the organ weight increased and reached that of the control group only in chickens that were feed-restricted from $\mathrm{d} 35$ to $\mathrm{d} 42$. In the starter period, proventriculus and gizzard were less affected by feed restriction. In the finisher period, the gizzard was also the least affected organ, while the small intestine was the most affected. All effects of feed restriction were reversed after 3 days of ad libitum refeeding, indicating that the alterations were fast and reversible. Moreover, response to feed restriction and refeeding is age dependent.
\end{abstract}

Key words: digestive enzymes, feed restriction, gastrointestinal organs, refeeding

J. Poult. Sci., 51: 289-296, 2014

\section{Introduction}

It is known that feed restriction affects chicken performance, leading to a decrease in the weight of the body and some organs, such as the pancreas and those of the digestive tract (Camacho et al., 2004; Wijtten et al., 2010). It can be expected that a decrease in digestive organ mass leads to similar alterations in digestive activity. In fact, a $70 \%$ reduction was observed in pancreatic enzyme activity for trypsin in 80\% feed-restricted chickens (Palo et al., 1995), and $25 \%$ and $10 \%$ reductions were observed for carboxypeptidase $\mathrm{A}$ and general proteolytic activity, respectively, in 40\% feed-restricted chickens (Susbilla et al., 2003).

As for intestinal enzymes, Fassbinder-Orth and Karasov (2006) detected a decrease in maltase activity. However, Pinheiro et al. (2004) observed an increase in sucrase activity but not in maltase activity $1 \mathrm{~d}$ following 70\% ad libitum feed

Received: June 2, 2013, Accepted: December 30, 2013

Released Online Advance Publication: February 25, 2014

Correspondence: Dr. C.R.A. Duarte, Department of Animal Science, Universidade Estadual de Maringá (UEM), Av. Colombo, 5790, Bloco j45, Maringá, Paraná, Brazil, 87020-900. (E-mail: crisrduarte@hotmail.com) restriction from 7 to $14 \mathrm{~d}$ of age, whereas Palo et al. (1995) observed an increase in intestinal maltase and sucrase activity 7 d after 4 d, 20\% ad libitum feed restriction.

The different levels of restriction used in studies make it difficult to draw a conclusion regarding the effect of feed restriction on enzyme activity. Moreover, it is important to consider the stage of development during which the feed restriction is imposed to the chickens, given that animal age can influence enzymatic levels (Iji et al., 2001; Sklan and Noy, 2003; Yegani and Korver, 2008) and metabolic rate (Christensen et al., 2012). Duarte et al. (2011) studied the effect of feed restriction on gene expression and showed that variations occur according to animal age. The mRNA abundance of aminopeptidase, but not that of maltase, increased in chickens that were feed-restricted in the starter and finisher periods, while the mRNA abundance of the sucraseisomaltase complex was higher only in chickens that were feed-restricted in the finisher periods (Duarte et al., 2011).

Another relevant question is whether animals of different ages can show the same capacity to recover the enzyme activity after refeeding. Most studies agree that gastrointestinal organ weight is reduced by feed restriction but is 
recovered by refeeding. Realimentation after feed restriction can improve feed efficiency and compensatory growth (Jang et al., 2009), and it is possible that this response can be attributed to the recovery of enzyme activity. Therefore, it is imperative to know the physiological changes that underlie feed restriction and subsequent realimentation to better understand animal nutrition and health. In particular, it is important to know which changes in the gastrointestinal tract are responsible for processing dietary nutrients necessary for self-maintenance and growth (Gilbert et al., 2008).

The present study compares the effects of feed restriction and subsequent realimentation on the activity of pancreatic chymotrypsin, trypsin, amylase and lipase and intestinal sucrase and maltase of broiler chickens between starter (from 7 to $17 \mathrm{~d}$ of age) and finisher (from 35 to $45 \mathrm{~d}$ of age) periods. In addition, the effects on gastrointestinal organ weight were also measured.

\section{Materials and Methods}

\section{Birds and Diets}

A total of 64 male broiler chicks (Cobb) were obtained from a commercial hatchery (Frigorífico Mabella Ltda, Tatuí, Brazil) on the day of hatching. The chicks were housed individually in metal batteries in an environmentally controlled room with constant illumination and controlled temperature $\left(22^{\circ} \mathrm{C}\right.$ to $31^{\circ} \mathrm{C}$, according to age). Water and food were offered ad libitum during the experiment, except for feed-restriction periods. Two diets (Table 1) were formulated according to Rostagno et al. (2005) and offered during the starter (from 1 to $14 \mathrm{~d}$ of age) and grower-finisher periods (from 35 to $45 \mathrm{~d}$ of age). All procedures were approved by the University Ethics Committee for Animal Research.

The effect of feed restriction (for $7 \mathrm{~d}$ ) and refeeding (for 3 d) on enzyme activity and organ weight was assessed in chickens at two different ages: 7 and $35 \mathrm{~d}$ of age. For each age, 32 birds were divided into two groups: feed-restricted $(n$

Table 1. Composition of experimental diets (\%)

\begin{tabular}{|c|c|c|}
\hline & $\begin{array}{l}\text { Starter }^{1} \text { diet } \\
1 \text { to } 14 d\end{array}$ & $\begin{array}{c}\text { Grower-Finisher }{ }^{2} \text { diet } \\
15 \text { to } 45 \mathrm{~d}\end{array}$ \\
\hline \multicolumn{3}{|l|}{ Ingredients } \\
\hline Soybean meal & 34.30 & 30.70 \\
\hline Corn & 59.34 & 62.03 \\
\hline Calcium calcite & 0.90 & 0.89 \\
\hline Dicalcium phosphate & 1.80 & 1.68 \\
\hline Soybean oil & 2.30 & 3.29 \\
\hline Salt & 0.47 & 0.47 \\
\hline L-Lysine & 0.20 & 0.25 \\
\hline L-Threonine & 0.05 & 0.05 \\
\hline DL-Methionine & 0.24 & 0.24 \\
\hline Mineral-vitamin $\operatorname{mix}^{1}$ & 0.40 & 0.40 \\
\hline \multicolumn{3}{|l|}{ Calculated analysis } \\
\hline ME (kcal/kg) & $3,002.97$ & $3,101.60$ \\
\hline Crude protein $(\%)$ & 20.80 & 19.43 \\
\hline Crude fiber $(\%)$ & 2.88 & 2.73 \\
\hline Calcium (\%) & 0.89 & 0.85 \\
\hline Available phosphorus (\%) & 0.44 & 0.42 \\
\hline Methionine (\%) & 0.53 & 0.51 \\
\hline Methionine + cysteine $(\%)$ & 0.81 & 0.78 \\
\hline Lysine $(\%)$ & 1.16 & 1.11 \\
\hline \multicolumn{3}{|c|}{ 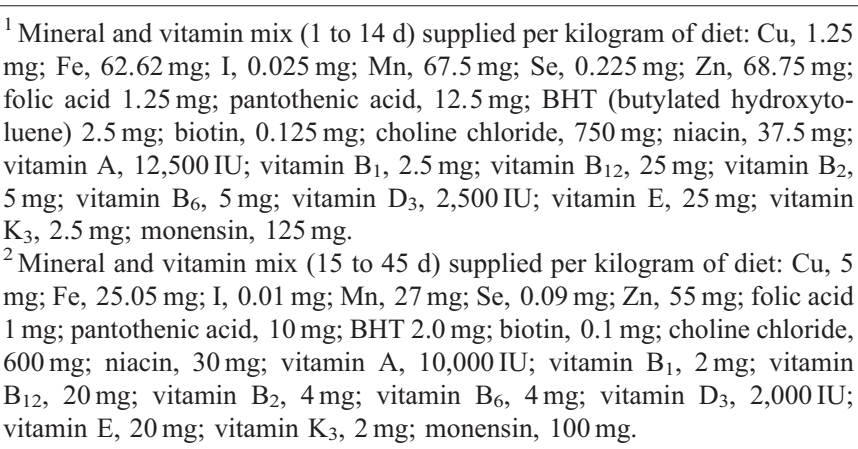 } \\
\hline
\end{tabular}


$=16), 30 \%$ of ad libitum intake, and control ( $n=16$, fed $a d$ libitum). Half of the birds in each group $(n=8)$ were sacrificed to evaluate the effects of feed restriction (d14 or $\mathrm{d} 42)$ and the other half $(n=8)$ were assessed for the effects of refeeding (d17 or $\mathrm{d} 45)$.

These chickens were also evaluated for changes in the genetic expression of intestinal enzymes and transporters. These results were published elsewhere (Duarte et al., 2011). The changes in the body weight of the animals, considered to be an indicator of the feeding restriction effect, were presented in that paper in a table. We consider this repetition to be inappropriate because the evaluation of body weight was not a primary goal in any of the previous papers.

\section{Organ Weight}

After feed restriction (d14 and d42) and the realimentation period ( $\mathrm{d} 17$ and $\mathrm{d} 45$ ), animals were sacrificed by cervical dislocation to collect the gastrointestinal organs (proventriculus, gizzard, small intestine, large intestine and pancreas). The organs were cleaned by flushing them with icecold saline solution $(\mathrm{NaCl}, 0.9 \%)$, dried with filter paper, and weighed.

\section{Enzyme Analysis}

The pancreas and jejunum were frozen in liquid nitrogen and stored in freezer at $-80^{\circ} \mathrm{C}$ until being assayed. The activity of the pancreatic enzymes was measured after the pancreas was homogenized $(1: 20 \mathrm{wt} / \mathrm{vol})$ in $50 \mathrm{mmol} / l$ Tris$\mathrm{HCl}$ buffer, $\mathrm{pH} 8.0$, containing $50 \mathrm{mmol} / l \mathrm{CaCl}_{2}$. For trypsinogen determination (Kakade et al., 1974), enterokinase was added to the homogenate and allowed to convert the enzyme into trypsin. Trypsin (E.C. 3.4.21.4) activity was then measured from the hydrolysis of p-nitroaniline from benzoyl-DL-arginine-p-nitroanilide (DL-BAPNA) at pH 8.2. Units are expressed as nanomoles of p-nitroanilide released per minute per milligram of protein. A similar method (Erlanger et al., 1966) was used for the determination of chymotrypsin (E.C. 3.4.21.1), with BAPNA replacing Nglutaryl-L-phenylalanine-p-nitroanilide (GPNA). The reaction was stopped with $3 \%$ acetic acid solution. Amylase (E.C. 3.2.1.1) was measured by the iodometric method (In vitro Diagnostica, Itabira, Brazil) modified by Caraway (1959) and the activity was expressed as amylase units (AU) per microgram of protein. One amylase unit is the amount of enzyme that hydrolyzes $10 \mathrm{mg}$ of starch in $30 \mathrm{~min}$. Lipase (E.C. 3.1.1.3) activity was measured using the BALB-DNTP method (In vitro Diagnostica). Accordingly, lipase hydrolyzes the thioester producing a thioalcohol that reacts with nitrobenzoic acid, yielding a yellow anion. The color intensity is proportional to the enzyme concentration. The enzyme activity was expressed in International Units (IU) per microgram of protein, which was measured according to Bradford (1976).

To measure the activity of intestinal disaccharidases by the Dahlqvist method (Dahlqvist, 1964), the jejunum was dissected lengthwise and the mucosa was scraped off with a glass microscope coverslip. The obtained tissue was mechanically homogenized after the addition of 4 parts of ice-cold deionized water. Maltase (E.C. 3.2.1.20) and sucrase (E.C.
3.2.1.10) activities were assayed by incubating aliquots of the homogenates with the appropriate substrate in malate buffer at $\mathrm{pH}$ 6.4. Released glucose was measured using the glucose-oxidase method (Laborlab, Guarulhos, Brazil). Enzyme activity is expressed in units per milligram of protein.

\section{Statistical Analyses}

Values are given as the means \pm SE. Differences between experimental groups and their respective controls for each age were analyzed using Student's t-test in GraphPad Prism 5.0 (GraphPad Software, Inc, La Jolla, CA, USA). The significance level was set at $P<0.05$.

\section{Results}

\section{Organ Weight}

The organ weights (Table 2) of feed-restricted chickens was lower than those in the control groups, regardless of age $(P<0.05)$. Upon refeeding, the organ weights of older chickens increased $(P<0.05)$ and reached those of the control group, while the organ weights of younger chickens remained lower.

When the organ weights were normalized with respect to body weight (Table 3 ), the proventriculus of feed-restricted animals was heavier at the starter (d14) and finisher periods (d42) than that of the control group. The gizzard $(P<0.05)$ of feed-restricted animals was heavier than that of the control group at the starter period. However, the small intestine relative weight was lower in feed-restricted chickens at the finisher period compared to the control group. The relative weights of the pancreas and large intestine were not affected by feed restriction at either age $(P>0.05)$.

Upon refeeding, the relative weights of all organs of animals feed-restricted during the finisher period (d45) increased and exceeded the values observed in the control group $(P<0.05)$. In the starter period $(\mathrm{d} 17)$, the same relationship were observed with the gizzard, proventriculus and small intestine, which were heavier than in the control group $(P<0.05)$.

\section{Pancreatic Enzymes}

Trypsin and amylase activity were lower $(P<0.05$, Table 4 ) in chickens that were feed-restricted from $\mathrm{d} 7$ to 14 . The pancreatic enzymes were not affected in animals feedrestricted from $\mathrm{d} 35$ to 42 . There was no difference between refed and control groups at both starter and finisher periods. The lipase and chymotrypsin activities were not affected by feeding regimen at any age $(P>0.05)$.

\section{Intestinal Enzymes}

The disaccharidase of younger chickens was not affected $(P>0.05$, Table 4$)$ either by feed restriction (d14) or realimentation (d17). In the older animals, the sucrase activity was lower $(P<0.05)$ in feed-restricted chickens $(\mathrm{d} 42)$ compared to that of the control group, and after refeeding (d45), the disaccharidase activity was similar to that of the control group $(P>0.05)$.

\section{Discussion}

Feed restriction has been widely studied during the starter phase of broiler development because this practice reduces 
Table 2. Organ weight (g) of chickens at 7 and $\mathbf{3 5} \mathbf{d}$ of age subjected to feed-restriction (7d) or to feed restriction (7d) followed by refeeding (3d)

\begin{tabular}{|c|c|c|c|c|}
\hline & \multicolumn{2}{|c|}{ Restriction effect } & \multicolumn{2}{|c|}{ Refeeding effect } \\
\hline & $\begin{array}{l}\text { Restricted } \\
\text { (7d) }\end{array}$ & $\begin{array}{l}\text { Control-7 } \\
\text { Ad libitum } \\
\quad(7 d)\end{array}$ & $\begin{array}{c}\text { Restricted }+ \\
\text { Refed } \\
(7 d+3 d)\end{array}$ & $\begin{array}{l}\text { Control-10 } \\
\text { Ad libitum } \\
\quad(10 \mathrm{~d})\end{array}$ \\
\hline $7 \mathrm{~d}$ of age & \multicolumn{2}{|c|}{ d14 } & \multicolumn{2}{|c|}{ d17 } \\
\hline Proventriculus & $1.53 \pm 0.05$ & $2.30 \pm 0.14^{*}$ & $2.76 \pm 0.11$ & $3.46 \pm 0.08 \dagger$ \\
\hline Gizzard & $6.62 \pm 0.14$ & $9.49 \pm 0.27 *$ & $9.80 \pm 0.27$ & $13.22 \pm 0.69 \dagger$ \\
\hline Small Intestine & $9.46 \pm 0.29$ & $16.85 \pm 1.40^{*}$ & $21.13 \pm 0.97$ & $28.40 \pm 1.05 \dagger$ \\
\hline Large Intestine & $1.52 \pm 0.12$ & $2.81 \pm 0.32 *$ & $2.86 \pm 0.15$ & $4.18 \pm 0.18 \dagger$ \\
\hline Pancreas & $0.79 \pm 0.06$ & $1.46 \pm 0.09 *$ & $1.69 \pm 0.17$ & $2.16 \pm 0.11 \dagger$ \\
\hline $35 \mathrm{~d}$ of age & \multicolumn{2}{|c|}{ d35 } & \multicolumn{2}{|c|}{ d42 } \\
\hline Proventriculus & $5.55 \pm 0.19$ & $6.74 \pm 0.23 *$ & $7.45 \pm 0.36$ & $7.11 \pm 0.37$ \\
\hline Gizzard & $26.75 \pm 0.99$ & $34.53 \pm 3.01 *$ & $36.47 \pm 2.30$ & $32.64 \pm 1.67$ \\
\hline Small Intestine & $32.04 \pm 1.21$ & $49.86 \pm 1.83 *$ & $52.78 \pm 3.57$ & $50.72 \pm 3.24$ \\
\hline Large Intestine & $9.43 \pm 0.54$ & $12.88 \pm 0.47^{*}$ & $14.36 \pm 0.76$ & $14.07 \pm 0.66$ \\
\hline Pancreas & $3.12 \pm 0.13$ & $4.00 \pm 0.16^{*}$ & $4.62 \pm 0.42$ & $4.54 \pm 0.24$ \\
\hline
\end{tabular}

Data are means $\pm \mathrm{SE}$

Control-7 and Control-10 indicate the control animals fed ad libitum by 7 and $10 \mathrm{~d}$, respectively.

* Indicates a significant difference between Restricted and Control-7 groups and $\dagger$ indicates a significant

difference between Restricted + refed and Control-10 groups (Student's $t$ - test, $P<0.05$ ).

Table 3. Relative organ weight (g/100 g of body weight) of chickens at 7 and $35 \mathrm{~d}$ of age subjected to feed-restriction (7d) or to feed restriction (7d) followed by refeeding (3d)

\begin{tabular}{|c|c|c|c|c|}
\hline & \multicolumn{2}{|c|}{ Restriction effect } & \multicolumn{2}{|c|}{ Refeeding effect } \\
\hline & $\begin{array}{l}\text { Restricted } \\
\qquad(7 d)\end{array}$ & $\begin{array}{l}\text { Control-7 } \\
\text { Ad libitum } \\
\quad(7 d)\end{array}$ & $\begin{array}{c}\text { Restricted }+ \\
\text { Refed } \\
(7 d+3 d)\end{array}$ & $\begin{array}{l}\text { Control-10 } \\
\text { Ad libitum } \\
\quad(10 \mathrm{~d})\end{array}$ \\
\hline 7 d of age & \multicolumn{2}{|c|}{ d14 } & \multicolumn{2}{|c|}{ d17 } \\
\hline Proventriculus & $0.95 \pm 0.03$ & $0.73 \pm 0.02 *$ & $0.90 \pm 0.03$ & $0.74 \pm 0.02 \dagger$ \\
\hline Gizzard & $4.09 \pm 0.25$ & $3.08 \pm 0.17 *$ & $3.20 \pm 0.09$ & $2.82 \pm 0.14 \dagger$ \\
\hline Small Intestine & $5.84 \pm 0.14$ & $5.33 \pm 0.22$ & $6.87 \pm 0.19$ & $6.07 \pm 0.21 \dagger$ \\
\hline Large Intestine & $0.95 \pm 0.08$ & $0.89 \pm 0.08$ & $0.93 \pm 0.05$ & $0.89 \pm 0.03$ \\
\hline Pancreas & $0.49 \pm 0.03$ & $0.47 \pm 0.02$ & $0.55 \pm 0.05$ & $0.46 \pm 0.02$ \\
\hline $35 \mathrm{~d}$ of age & \multicolumn{2}{|c|}{ d35 } & \multicolumn{2}{|c|}{ d42 } \\
\hline Proventriculus & $0.30 \pm 0.01$ & $0.27 \pm 0.01 *$ & $0.35 \pm 0.01$ & $0.27 \pm 0.01 \dagger$ \\
\hline Gizzard & $1.46 \pm 0.06$ & $1.39 \pm 0.12$ & $1.72 \pm 0.07$ & $1.25 \pm 0.05 \dagger$ \\
\hline Small Intestine & $1.74 \pm 0.05$ & $2.01 \pm 0.06^{*}$ & $2.49 \pm 0.12$ & $1.94 \pm 0.09 \dagger$ \\
\hline Large Intestine & $0.51 \pm 0.03$ & $0.52 \pm 0.02$ & $0.68 \pm 0.03$ & $0.54 \pm 0.02 \dagger$ \\
\hline Pancreas & $0.17 \pm 0.01$ & $0.16 \pm 0.01$ & $0.21 \pm 0.01$ & $0.17 \pm 0.01 \dagger$ \\
\hline
\end{tabular}

Data are means \pm SE

Control-7 and Control-10 indicate the control animals fed ad libitum by 7 and $10 \mathrm{~d}$, respectively.

* Indicates a significant difference between Restricted and Control-7 groups and $\dagger$ indicates a significant difference between Restricted + refed and Control-10 groups (Student's $t$ - test, $P<0.05$ ).

metabolic disorders and reproductive problems, and controls excess weight gain (Camacho et al., 2004). During this phase, the gastrointestinal tract develops rapidly compared to the rest of the body, while enzyme and absorption activities in the intestinal epithelium also increase swiftly (Uni et al., 1998). Although feed restriction can be applied after the first two weeks of life to improve productive efficiency, decrease carcass fat content, and reduce mortality rates (UrdanetaRincon and Leeson, 2002), there is a shortage of literature on the effects of this practice on the gastrointestinal tract of growth-phase chickens. Given that the development of gastrointestinal organs and enzymatic levels change depend- 
Table 4. Pancreatic and intestinal enzyme activity of chickens at 7 and $35 \mathrm{~d}$ of age subjected to feed-restriction (7d) or to feed restriction (7d) followed by refeeding (3d)

\begin{tabular}{|c|c|c|c|c|}
\hline & \multicolumn{2}{|c|}{ Restriction effect } & \multicolumn{2}{|c|}{ Refeeding effect } \\
\hline & $\begin{array}{l}\text { Restricted } \\
\qquad(7 d)\end{array}$ & $\begin{array}{l}\text { Control-7 } \\
\text { Ad libitum } \\
\quad(7 d)\end{array}$ & $\begin{array}{c}\text { Restricted }+ \\
\text { Refed } \\
(7 d+3 d)\end{array}$ & $\begin{array}{l}\text { Control-10 } \\
\text { Ad libitum } \\
\quad(10 \mathrm{~d})\end{array}$ \\
\hline $7 \mathrm{~d}$ of age & \multicolumn{2}{|c|}{ d14 } & \multicolumn{2}{|c|}{ d17 } \\
\hline $\begin{array}{l}\text { Trypsin } \\
\text { (nmol/mg protein) }\end{array}$ & $46.3 \pm 5.0$ & $75.0 \pm 13.8 *$ & $112.1 \pm 5.3$ & $123.8 \pm 22.7$ \\
\hline $\begin{array}{l}\text { Chymotrypsin } \\
\text { (nmol/mg protein) }\end{array}$ & $2.6 \pm 0.2$ & $3.0 \pm 0.8$ & $4.4 \pm 0.4$ & $4.4 \pm 1.3$ \\
\hline 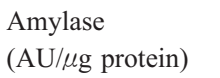 & $3.1 \pm 0.4$ & $4.8 \pm 0.6^{*}$ & $3.8 \pm 0.7$ & $2.4 \pm 0.5$ \\
\hline  & $1.5 \pm 0.2$ & $1.5 \pm 0.1$ & $1.7 \pm 0.1$ & $2.2 \pm 0.3$ \\
\hline $\begin{array}{l}\text { Sucrase } \\
\text { (U/mg protein) }\end{array}$ & $1.9 \pm 0.2$ & $2.3 \pm 0.2$ & $2.3 \pm 0.2$ & $2.2 \pm 0.2$ \\
\hline $\begin{array}{l}\text { Maltase } \\
\text { (U/mg protein) }\end{array}$ & $3.9 \pm 0.7$ & $4.0 \pm 0.5$ & $3.4 \pm 0.4$ & $3.0 \pm 0.2$ \\
\hline $35 \mathrm{~d}$ of age & \multicolumn{2}{|c|}{ d35 } & \multicolumn{2}{|c|}{ d42 } \\
\hline $\begin{array}{l}\text { Trypsin } \\
\text { (nmol/mg protein) }\end{array}$ & $197.2 \pm 14.2$ & $173.1 \pm 11.8$ & $169.5 \pm 5.1$ & $200.1 \pm 27.2$ \\
\hline $\begin{array}{l}\text { Chymotrypsin } \\
\text { (nmol/mg protein) }\end{array}$ & $4.2 \pm 0.7$ & $5.9 \pm 0.7$ & $4.0 \pm 0.8$ & $5.7 \pm 1.2$ \\
\hline 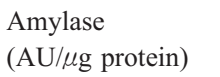 & $3.7 \pm 1.0$ & $4.6 \pm 1.3$ & $3.6 \pm 0.5$ & $2.8 \pm 0.2$ \\
\hline $\begin{array}{l}\text { Lipase } \\
\text { (IU/ } / \mu \mathrm{g} \text { protein) }\end{array}$ & $2.3 \pm 0.4$ & $2.5 \pm 0.2$ & $1.5 \pm 0.4$ & $1.0 \pm 0.2$ \\
\hline $\begin{array}{l}\text { Sucrase } \\
\text { (U/mg protein) }\end{array}$ & $2.3 \pm 0.1$ & $3.2 \pm 0.4^{*}$ & $2.3 \pm 0.4$ & $2.1 \pm 0.2$ \\
\hline $\begin{array}{l}\text { Maltase } \\
\text { (U/mg protein) }\end{array}$ & $3.6 \pm 0.4$ & $4.8 \pm 0.8$ & $2.9 \pm 0.7$ & $3.5 \pm 0.5$ \\
\hline
\end{tabular}

Data are means $\pm \mathrm{SE}$

Control-7 and Control-10 indicate the control animals fed ad libitum by 7 and $10 \mathrm{~d}$, respectively. * Indicates a significant difference between control and restricted groups. (Student's $t$ - test, $P<$ $0.05)$

ing on age (Iji et al., 2001; Sklan and Noy, 2003; Yegani and Korver, 2008), it is very important to consider the stage of development during which feed restriction is imposed on chickens.

Thus, the innovation of the present study was to show the age-dependent sensitivity of digestive enzymes to malnutrition in chickens and the reversal of decreased enzyme activity within $3 \mathrm{~d}$ of refeeding. The enzyme activity observed herein also cannot be explained by diet alone (Chotinsky et al., 2001) and supports the fact that each digestive enzyme has its own sensitivity to malnutrition (Susbilla et al., 2003). It was demonstrated that feedrestriction in younger birds causes a decrease in the activities of pancreatic trypsin and amylase, but not in the activities of chymotrypsin, lipase and intestinal enzymes. In older animals, there is a decrease only in intestinal sucrase.

The decrease in pancreatic enzyme activity in younger animals is supported by the report by Palo et al. (1995) on chickens that were feed-restricted for $7 \mathrm{~d}$, which could be attributed to a decrease in protein synthesis, given that fasting inhibited pancreatic protein synthesis in mice (Sans et al., 2004). Moreover, protein restriction inhibited the response of acinar cells to cholecystokinin (Prost and Belleville, 1991), which plays a role in stimulating enzyme secretion in the pancreas. A similar response was observed in mice that were fed a protein-restricted diet for $4 \mathrm{~d}$, and a decrease in pancreas weight and pancreatic cell atrophy was observed under these conditions (Crozier et al., 2009). Although chickens of both ages showed a decrease in pancreas weight, there was a larger reduction in younger animals - approximately $50 \%$ compared with $22 \%$ in older animals - thus contributing to the large difference in pancreatic enzymes between age groups.

Our findings regarding maltase activity are supported by Fassbinder-Orth and Karasov (2006), in which the jejunal and ileal maltase activities of young animals were not 
affected by feed restriction. Maltase activity results were also correlated with the response of mRNA expression previously observed in our laboratory (Duarte et al., 2011), which suggests that this gene can have a pre-transcriptional regulation (Gal-Garber et al., 2000). With regard to intestinal sucrase, our results in younger chickens were different from Pinheiro et al. (2004), who observed an increase in enzyme activity in $14 \mathrm{~d}$ of age chickens that were $30 \%$ feed-restricted for $7 \mathrm{~d}$. This difference could be attributed to a difference between the level and duration of feed restriction employed by Pinheiro et al. (2004). Sucrase activity appeared to be of post-transcriptionally regulated, which also occurs with other enzymes and transporters (Ihara et al., 2000; Duarte et al., 2011). In fact, comparing our results with the results of Duarte et al. (2011) on mRNA expression, it is possible to conclude that the results are independent of the mRNA level.

It is worth mentioning that on the third day of refeeding, the activities of all enzymes was not different from those of the control. In their study, Crozier et al. (2009) verified that after $4 \mathrm{~d}$ of receiving a normoproteic diet, protein-restricted mice showed a reversal of the decreased concentration of amylase and chymotrypsin. The restoration of enzyme activity could occur because pancreatic cell death did not occur after feed restriction, and instead, only cell atrophy or a decrease in protein synthesis in the pancreas occurred (Sans et al., 2004). Pancreatic cells were not evaluated in this study, but it is possible that there was no atrophy, given that after $3 \mathrm{~d}$ of refeeding, the pancreas weight was similar to the control in younger chickens and higher than the control in older animals. The recovery can be explained by an increase in pancreatic protein synthesis as shown by Sans et al. (2004). However, these authors did not show a related increase in the mRNA levels of the digestive enzymes, which was most likely due to the shorter refeeding time $(2 \mathrm{~h}$ of refeeding). Moreover, for intestinal activity, the recovery can be explained by the replacement of the enterocytes used in enzyme expression during the refeeding period, as indicated by Yamauchi and Tarachai (2000), who showed a rapid recovery of villus height through increased epithelial cell area and cell mitosis after $1 \mathrm{~d}$ of refeeding in chickens.

Although there are discrepancies in the literature concerning the effects of feed restriction on the gastrointestinal system, the observed reduction in organ weights at both ages is an expected response given the trophic effects of nutrients (Fassbinder-Orth and Karasov 2006; Wijtten et al., 2010) and the reduction in the basal metabolic rate in response to feed restriction (Christensen et al., 2012). A decrease in metabolic rate could lead to a reduction in the energy required to maintain gastrointestinal turnover. In fact, feed restriction affects intestinal villus height, cell area, cell proliferation, and mitosis rate (Shamoto and Yamauchi 2000).

It is well known that adequate development of the digestive system, especially of the small intestine, is essential for food digestion and absorption and, consequently, for animal nutrition. Thus, the reduction of gastrointestinal organs observed in this study may have contributed to the decrease in body weight observed in chickens that were feed restricted during the starter and finisher periods (Duarte et al., 2011).

However, age influenced the organ response after refeeding. In fact, although it is known that the recovery of the small intestine is rapid in response to refeeding (Yamauchi et $a l ., 1996)$, only older feed-restricted animals could reach the same absolute organ weights as those of the control group. This different response may be caused by a lower basal metabolic rate and maintenance requirements typical of old chickens (Zubair and Leeson 1994; Tona et al., 2004). In addition, feed restriction shows more deleterious effects when it is applied in the first week post-hatch (Uni et al., 2003; Tabedian et al., 2010). The feed-restriction of chickens at 6 weeks of age caused an increase in the jejunal villus height, which was regarded as an adaptive strategy to maximize nutrient uptake once feeding was reestablished (Thompson and Applegate 2006).

Other results from feed restriction were found when the organ weights were normalized relative to body weight. The relative weight of the proventriculus in starter and finisher periods and the weight of the gizzard in starter periods were higher than those of the control, showing that these organs were less affected by feed restriction than body weight.

Hypertrophy of the gizzard was also observed in broilers that were $30 \%$ feed-restricted from 7 to $14 \mathrm{~d}$ (Lázaro et al., 2004). According to Govaerts et al. (2000), birds that are feed-restricted can give priority to the development of supply organs, such as the proventriculus and gizzard, at the expense of the growth of demand tissues, such as the breast and thigh.

The relative weight of the large intestine did not change in response to feed restriction in both ages. Lázaro et al. (2004) also did not find differences in the length of ceca between the control and 30\% feed-restricted chickens from 4 to $14 \mathrm{~d}$. Similarly, chickens fed a low-protein diet did not show in a change in weight of the large intestine (Buwjoom et al., 2010). However, the large intestine in rats that were feed restricted exhibited a susceptibility to acute changes in nutrient supply, with lower protein content and lower rates of protein synthesis (Merry et al., 1991). However, these authors showed that the large intestine is less responsive than the small intestine to acute changes in nutrient supply. Changes in this organ could also indicate the existence of an inflammatory process caused by pathogen adhesion. However, reports concerning the effects of feed restriction on the large intestine in chickens are scarce.

In conclusion, this study showed that the changes caused by feed restriction are fast and reversible given that enzymatic activity and organ weight were similar to those of the control groups after 3 days of ad libitum feeding. Our data contributed to the knowledge of the adaptive changes of chickens to malnutrition and showed that the response to feed restriction varies according to age.

\section{Acknowledgments}

Grants from National Council for Scientific and Tech- 
nological Development (CNPq/Brazil).

\section{References}

Bradford MM. A rapid and sensitive method for the quantitation of microgram quantities of protein utilizing the principle of protein-dye binding. Analytical Biochemistry, 72: 248-254. 1976.

Buwjoom T, Yamauchi K, Erikawa T and Goto H. Histological intestinal alterations in chickens fed low protein diet. Journal of Animal Physiology and Animal Nutrition, 94: 354-361. 2010.

Camacho MA, Suárez ME, Herrera JG, Cuca JM and García-Bojalil CM. Effect of age of feed restriction and microelement supplementation to control ascites on production and carcass characteristics of broilers. Poultry Science, 83: 526-532. 2004.

Caraway WT. A stable starch substrate for the determination of amylase in serum and other body fluids. American Journal of Clinical Pathology, 32: 97-99. 1959.

Chotinsky D, Toncheva E and Profirov Y. Development of disaccharidase activity in the small intestine of broiler chickens. British Poultry Science, 42: 389-393. 2001.

Christensen K, Thaxton YV, Thaxton JP and Scanes CG. Change in body temperature during growth and in response to fasting in growing modern meat type chickens. British Poultry Science, 53: 531-537. 2012.

Crozier SJ, D'Alecy LG, Ernst SA, Ginsburg LE and Williams JA. Molecular mechanisms of pancreatic dysfunction induced by protein malnutrition. Gastroenterology, 137: 1093-1101. 2009.

Dahlqvist A. Method for assay of intestinal disaccharidases. Analytical Biochemistry, 7: 18-25. 1964.

Duarte CRA, Vicentini-Paulino MLM, Buratini Jr. J, Castilho ACS and Pinheiro DF. Messenger ribonucleic acid abundance of intestinal enzymes and transporters in feed-restricted and refed chickens at different ages. Poultry Science, 90: 863-868. 2011.

Erlanger BF, Edel F and Cooper AG. The action of chymotrypsin on two new chromogenic substrates. Archives of Biochemistry and Biophysics, 115: 206-210. 1966.

Fassbinder-Orth CA and Karasov WH. Effects of feed restriction and realimentation on digestive and immune function in the Leghorn chick. Poultry Science, 85: 1449-1456. 2006.

Gal-Garber O, Mabjeesh SJ, Sklan D and Uni Z. Partial sequence and expression of the gene for and activity of the sodium glucose transporter in the small intestine of fed, starved and refed chickens. Journal of Nutrition, 130: 2174-2179. 2000.

Gilbert ER, Wong EA and Webb Jr. KE. Peptide absorption and utilization: Implications for animal nutrition and health. Journal of Animal Science, 86: 2135-2155. 2008.

Govaerts T, Room G, Buyse J, Lippens M, De Groote G and Decuypere E. Early and temporary quantitative food restriction of broiler chickens. 2. Effects on allometric growth and growth hormone secretion. British Poultry Science, 41: 355-362. 2000.

Ihara T, Tsujikawa T, Fujiyama $\mathrm{Y}$ and Bamba T. Regulation of PepT-1 peptide transporter expression in the rat small intestine under malnourished conditions. Digestion, 61: 59-67. 2000.

Iji PA, Saki A and Tivey DR. Body and intestinal growth of broiler chicks on a commercial starter diet. 2. Development and characteristics of intestinal enzymes. British Poultry Science, 42: 514-522. 2001.

Jang IS, Kang SY, Ko YH, Moon YS and Sohn SH. Effect of qualitative and quantitative feed restriction on growth performance and immune function in broiler chickens. Asian-
Australasian Journal of Animal Science, 22: 388-395. 2009.

Kakade ML, Rackis JJ, McGhee JE and Puski G. Determination of trypsin inhibitor activity of soy products: A collaborative analysis of an improved procedure. Cereal Chemistry, 51: 376-381. 1974.

Lázaro R, Latorre MA, Medel P, Gracia M and Mateos GG. Feeding regimen and enzyme supplementation to rye-based diets for broilers. Poultry Science, 83: 152-160. 2004.

Merry BJ, Goldspink DF and Lewis SE. The effects of age and chronic restricted feeding on protein synthesis and growth of the large intestine of the rat. Comparative Biochemistry and Physiology - Part A: Comparative Physiology, 98A: 559-562. 1991.

Palo PE, Sell JL, Piquer FJ, Soto-Salanova MF and Vilaseca L. Effect of early nutrient restriction on broiler chickens. 1 . Performance and development of the gastrointestinal tract. Poultry Science, 74: 88-101. 1995.

Pinheiro DF, Cruz VC, Sartori JR and Vicentini-Paulino MLM. Effect of early feed restriction and enzyme supplementation on digestive enzyme activities in broilers. Poultry Science, 83: 1544-1550. 2004.

Prost J and Belleville J. Age and protein restriction followed by balanced refeeding affect pancreatic digestive enzyme outputs and turnover times in rats. Journal of Nutrition, 121: 20442054. 1991.

Rostagno HS, Albino LFT, Donzele JL, Gomes PC, Oliveira RF, Lopes DC, Ferreira AS and Barreto SLT. Tabelas brasileiras para aves e suínos: Composição de alimentos e exigências nutricionais. 2nd ed. Universidade Federal de Viçosa. (Viçosa). 2005.

Sans MD, Lee SH, D'Alecy, LG and Williams JA. Feeding activates protein synthesis in mouse pancreas at the translational level without increase in mRNA. American Journal of Physiology - Gastrointestinal and Liver Physiology, 287: G667-G675. 2004.

Shamoto K and Yamauchi K. Recovery responses of chick intestinal villus morphology to different refeeding procedures. Poultry Science, 79: 718-723. 2000.

Sklan D and Noy Y. Functional development and intestinal absorption in the young poult. British Poultry Science, 44: 651-658. 2003.

Susbilla JP, Tarvid I, Gow CB and Frankel TL. Quantitative feed restriction or meal-feeding of broiler chicks alter functional development of enzymes for protein digestion. British Poultry Science, 44: 698-709. 2003.

Tabedian SA, Samie A, Pourreza J and Sadeghi GH. Effect of fasting or post-hatch diet's type on chick development. Journal of Animal and Veterinary Advances, 9: 406-413. 2010.

Thompson KL and Applegate TJ. Feed withdrawal alters smallintestinal morphology and mucus of broilers. Poultry Science, 85: 1535-1540. 2006.

Tona K, Onagbesan OM, Bruggeman V, Mertens K, Yego Y and Decuypere E. Comparison of feed intake, blood metabolic parameters, body and organ weights of growing broilers originating from dwarf and standard broiler breeder lines. International Journal of Poultry Science, 3: 422-426. 2004.

Uni Z, Ganot S and Sklan D. Posthatch development of mucosal function in the broiler small intestine. Poultry Science, 77: 75-82. 1998.

Uni Z, Smirnov A and Sklan D. Pre- and posthatch development of globet cells in the broiler small intestine: effect of delayed access to feed. Poultry Science, 82: 320-327. 2003. 
Urdaneta-Rincon M and Leeson S. Quantitative and qualitative feed restriction on growth characteristics of male broiler chickens. Poultry Science, 81: 679-688. 2002

Wijtten PJ, Hangoor E, Sparla JK and Verstegen MW. Dietary amino acid levels and feed restriction affect small intestinal development, mortality, and weight gain of male broilers. Poultry Science, 89: 1424-1439. 2010.

Yamauchi K, Kamisoyama H and Isshiki Y. Effects of fasting and refeeding on structures of the intestinal villi and epithelial cells in White Leghorns hens. British Poultry Science, 37: 909-921.
1996.

Yamauchi K and Tarachai P. Changes in intestinal villi, cell area and intracellular autophagic vacuoles related to intestinal function in chickens. British Poultry Science, 41: 416-423. 2000.

Yegani $\mathrm{M}$ and Korver DR. Factors affecting intestinal health in poultry. Poultry Science, 87: 2052-2063. 2008.

Zubair AK and Leeson S. Effect of varying period of early nutrient restriction on growth compensation and carcass characteristics of male broilers. Poultry Science, 73: 129-136. 1994. 